\title{
Changes in the Epilimnetic Bacterial Community Composition, Production, and Protist-Induced Mortality along the Longitudinal Axis of a Highly Eutrophic Reservoir
}

\author{
K. Šimek, ${ }^{1,2}$ J. Armengol, ${ }^{3}$ M. Comerma, ${ }^{3}$ J.C. Garcia, ${ }^{3}$ P. Kojecka, ${ }^{2}$ J. Nedoma, ${ }^{1}$ J. Hejzlar ${ }^{1,2}$ \\ ${ }^{1}$ Hydrobiological Institute, Academy of Sciences of the Czech Republic, Na sádkách 7, CZ-37005 České \\ Budějovice, Czech Republic \\ ${ }^{2}$ Faculty of Biological Sciences, University of South Bohemia, Na sádkách 7, CZ-37005 České Budějovice, \\ Czech Republic \\ ${ }^{3}$ Department of Ecology, University of Barcelona, Av. Diagonal 645, E-08028, Barcelona, Spain
}

Received: 18 October 2000; Accepted: 2 March 2001; Online Publication: 9 July 2001

\section{A}

We studied changes in the epilimnetic bacterial community composition (BCC), bacterial biomass and production, and protistan succession and bacterivory along the longitudinal axis of the canyonshaped, highly eutrophic Sau Reservoir (NE Spain) during two sampling campaigns, in April and July 1997. Longitudinal changes in BCC from the river inflow to the dam area of the reservoir were detected by using oligonucleotide probes targeted to the kingdom Bacteria, to the alpha, beta, and gamma subclasses (ALFA, BETA, and GAMA) of the class Proteobacteria, and to the Cytophaga/ Flavobacterium (CF) cluster. In general, the inflow of the organically loaded Ter river, with highly abundant allochthonous bacterial populations, induced a clearly distinguishable longitudinal succession of the structure of the microbial food web. The most dynamic changes in microbial parameters occurred at the plunge point, the mixing area of river water and the reservoir epilimnion. Changes within members of BETA and CF were the most important in determining changes in BCC, bacterial abundance and biomass. Much less relevant changes occurred within the less abundant ALFA and GAMA bacteria. From the plunge point downstream, we described a significant shift in BCC in the form of decreased proportions of BETA and CF. This shift spatially coincided with the highest values of heterotrophic nanoflagellate bacterivory (roughly doubled the bacterial production). CF numerically dominated throughout the reservoir without any marked longitudinal changes in their mean cell volume. In contrast, very large cells affiliated to BETA clearly dominated in the allochthonous bacterial biomass brought by the river. BETA showed a marked downstream trend of decreasing mean cell volume. We conclude that the observed BCC shift and the longitudinal shift in food web structure (bacteria-heterotrophic nanoflagellates-ciliates) resulted from 
highly complex interactions brought about by several major factors: varying hydrology, the high localized allochthonous input of organic matter brought by the river, downstream changing substrate availability, and selective protistan bacterivory.

\section{Introduction}

During the past decade, the role and functioning of microbial food webs have been intensively studied in lakes of different trophic status and of different morphology (e.g., [7, $31,50])$. However, much less attention has been paid to the functioning of microbial food webs in dam reservoirs. There are significant differences between lake and reservoir ecosystems, among which the canyon-shaped ones differ most conspicuously $[41,43]$ by their relatively short retention time and longitudinal inhomogeneity. Canyon-shaped reservoirs represent highly specific, remarkably spatially heterogeneous systems. Selected aspects of them, i.e., hydrodynamics, chemical processes, and zoo-, phytoplankton, and protistan dynamics, have been already reported [10, 18, 33, 35, 37]. However, the dominating biogeochemical processes occurring in the upper parts of canyon-shaped reservoirs, mediated mainly by microbial activities and interactions [43], are not yet fully understood. Reservoir morphology and continuous supply of substrates by a river on the one hand, and the small size and high growth rates of planktonic microorganisms on the other hand, result in longitudinally different phases of microbial succession. Some of the general features and major factors operating in the processes that induce the longitudinally distinguishable succession of microbial populations in organically loaded reservoirs might be compared to a natural "sequencial reactor," such as a wastewatertreatment lagoon that reduces the concentration of easily degradable organic material from the inflow [44].

The upper, inflow parts are likely to show much more pronounced gradients in microbial food web dynamics since they represent highly productive ecotones between riverine and lacustrine systems, whereas the downstream parts of reservoirs behave more like lake ecosystems (with less marked gradients in microbial food webs). Depending on actual temperature stratification and the type of water circulation, a varying proportion of the river inflow is injected into the reservoir epilimnion, inducing the downstream trophic gradient through the reservoir. Generally, more pronounced gradients are likely to be expected when the river water parameters, namely nutrient and organic material loadings, differ from those in the lacustrine part of the res- ervoir. This is most evident in typical canyon-shaped reservoirs with well-developed thermal stratification, where the riverine and lacustrine parts are spatially separated by the transient zone where the inflow stream plunges to deeper strata depending on its density $[41,43]$.

The Sau Reservoir (NE Spain) represents a system with an extreme amount of nutrient and organic matter loading in its inflow part [46], which supports the establishment of strong gradients in chemical and biological parameters. Armengol et al. [4] and Comerma et al. [10] have reported distinguishable longitudinal gradients in concentrations of nutrients, in dissolved and particulate organic and inorganic material, and in bacterial and phytoplankton biomasses, yielding marked changes in turbidity and in qualitative parameters of water from the Ter river inflow to the outflow near the dam of the reservoir. A typical longitudinal succession of planktonic foods web structures in the Sau Reservoir, i.e., dominated by bacteria, heterotrophic nanoflagellates, ciliates, and rotifers, has been recently documented [10]. Moreover, detailed studies on protistan succession and bacterivory along the longitudinal axis of the reservoir showed distinct peaks of heterotrophic nanoflagellates and ciliate abundance, and consequently spatially changing roles of these protistan groups as bacterivores [10,37].

High input of allochthonous organic material, enhanced bacterial activity, and low oxygen saturation of water are typical for the inflow parts of the reservoir $[4,10]$, pointing to the essential role of bacteria in carbon and nutrient cycling. Given the clearly distinguishable chemical gradients and longitudinal succession of plankton populations (see above), it is conceivable that different phylogenetic groups of bacteria take part in the processes of organic matter transformation in the different parts of the reservoir.

In the past decade, new information on bacterial community composition (BCC) in aquatic environments has been obtained using in situ hybridization with oligonucleotide rRNA-targeted probes [2]. This approach has already distinguished some common and specific features of BCC in different freshwater environments covering a range from oligotrophic lakes $[1,26]$, through oligo-mesotrophic lakes [11, 22,49 ] or eutrophic reservoirs [38], to activated sludge systems [21, 47]. Although canyon-shaped reservoirs are 


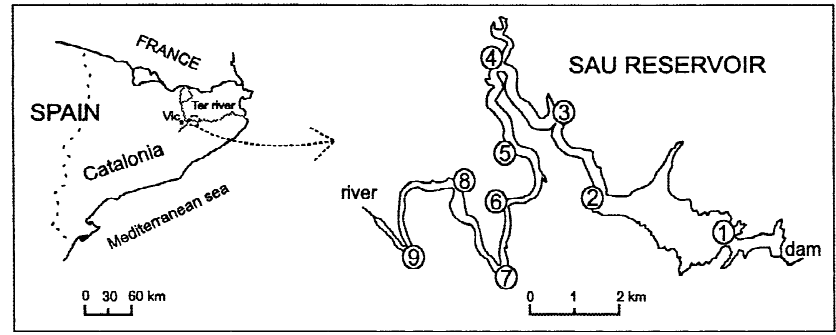

Fig. 1. The location of the Sau Reservoir in the Iberian Peninsula and the position of the nine sampling stations along the longitudinal axis of the reservoir.

unique, highly dynamic systems that involve a range of trophic gradient within the same water body, no specific study on changing phylogenetic bacterial composition on such longitudinally highly heterogeneous systems has been conducted.

In the present study we analyzed changes in the epilimnetic BCC, bacterial biomass and production, and protistan bacterivory along the longitudinal axis of the canyonshaped, highly eutrophic Sau Reservoir on two sampling occasions during 1997. We addressed the following questions: (1) Which microbial phyla dominate in the reservoir? (2) Does BCC significantly differ between the riverine and lacustrine parts of the reservoir? (3) Can the prevalence of particular bacterial groups be related to allo- versus autochthonous sources of organic substrates? (4) Can physical, chemical, or biological factors (i.e., changing substrate availability and protistan grazing) mediate the longitudinal BCC shifts? (5) Is there a reproducible, longitudinal pattern of protozoan successions related to the high allochthonous bacterial and organic matter loads?

\section{Materials and Methods}

Study Site and Sampling Scheme

The eutrophic Sau Reservoir is an $18.5 \mathrm{~km}$ long, canyon-type reservoir located in the middle stretch of the river Ter (Catalonia, NE Spain, 426 m.a.s.l., area $7.6 \mathrm{~km}^{2}$, volume $167 \times 10^{6} \mathrm{~m}^{3}$, max. depth $75 \mathrm{~m}$, mean depth $25.2 \mathrm{~m}$, mean retention time 88 days, dimictic, eutrophic). For a detailed description of the reservoir see Vidal and Om [46]. Water samples were collected at nine sampling points (equidistant $\sim 1.8 \mathrm{~km}$, see Fig. 1) along the longitudinal axes of the Sau Reservoir in two intensive sampling campaigns: in April 1997, when temperature of the river inflow was the same as that of the epilimnetic reservoir water $\left(\sim 16^{\circ} \mathrm{C}\right)$ and in July 1997, with well developed water stratification (for details see Comerma et al. [10]). In both cases, except for the shallow river inflow (station 9), mixed water samples from the epilimnetic top 3 meters were taken with a 3-meter long plastic tube. Three samples from each station were mixed in a 10-liter plastic container corresponding to a final volume of 9 liters.

\section{Bacterial Abundance and Biomass}

Duplicated subsamples were fixed with formaldehyde (2\% final concentration), stained with DAPI (final concentration $0.2 \% \mathrm{wt} /$ vol), and enumerated by epifluorescence microscopy (Olympus BX 60). Between 450 and 800 DAPI-stained bacterial cells were recorded at a magnification $1000 \times$ with an analog monochrome LCD camera Cohu mounted on the Olympus BX 60 microscope and processed with the semiautomatic image analysis systems LUCIA D (LUCIA 3.52, resolution $750 \times 520$ pixels, 256 gray levels, Laboratory Imaging, Prague, Czech Republic, http://www.lim.cz). Details of the image processing (gray transformation, edge finding) are described in Posch et al. [29]. Bacterial biomass was calculated according to the allometric relationship between cell volume and carbon content [24]. As the variation in cell width was rather small and mostly below the minimal size differences reliably detectable by image analysis, we chose the variation in cell length to subdivide bacteria into 5 size classes (in $\mu \mathrm{m}$ ): $<0.5,0.5-1,1-2,2-3$, and $>3$.

\section{Bacterial Production}

Bacterial production was measured via thymidine incorporation according to the method of Bell [6]. Five 5-ml subsamples were incubated for $30 \mathrm{~min}$ at in situ temperature with $20 \mathrm{nmol}$ liter $^{-1}$ of [methyl- ${ }^{3} \mathrm{H}$ ] thymidine (DUPON Corp.), then fixed with neutral buffered formaldehyde ( $2 \%$ final concentration), filtered through $0.2-\mu \mathrm{m}$ cellulose-nitrate membrane filters (Whatman), and extracted 4 times with $1 \mathrm{ml}$ of ice-cold 5\% TCA followed by 5 washes of $1 \mathrm{ml}$ of ice-cold $80 \%$ ethanol. Replicate blanks prefixed by $2 \%$ formaldehyde were processed in parallel. To determine empirical conversion factor (ECF) between thymidine incorporation rate and bacterial cell production rate in April 1997, replicate 750-ml subsamples of water filtered through $1-\mu \mathrm{m}$ filters (Poretics) were incubated for $24 \mathrm{~h}$ in dark at in situ temperature. The cell production rate was calculated from the slope of the increase of $\ln$ bacterial abundance over time $(0,12,24 \mathrm{~h})$. The average ECF $(4.7 \pm 1.38 \times$ $10^{18}$ cells $\mathrm{mol}^{-1}$ ) was used for calculations of the bacterial production in April 1997 and a theoretical conversion factor of $2 \times 10^{18}$ cells $\mathrm{mol}^{-1}$ thymidine incorporated was used for the data from July 1997.

\section{Fluorescence in Situ Hybridization of Bacteria with Group Specific Oligonucleotide RNA-Targeted Probes}

A crude analysis of bacterial community structure was carried out by fluorescence in situ hybridization (FISH) with oligonucleotide probes on membrane filters $[1,11]$. Duplicated reservoir samples were prefixed with alkaline Lugol's solution followed by formalde- 
hyde $(2 \% \mathrm{w} / \mathrm{v}$, final concentration) for at least $1 \mathrm{~h}$, and decolorized by addition of several drops of a $3 \%$ solution of sodium thiosulfate to prevent cell disruption of planktonic algae and of other fragile flagellated plankters. Bacterial cells from 10-20 ml subsamples were concentrated on white $0.2-\mu \mathrm{m}$-pore-size filters (Poretics Corp.; 47$\mathrm{mm}$ diameter), rinsed with distilled water, and stored frozen at $-20^{\circ} \mathrm{C}$ until further processing. FISH of filter sections with the five different oligonucleotide probes targeted to the kingdom Bacteria (EUB), the alpha, beta, and gamma subclasses of Proteobacteria (ALFA, BETA, GAMA), and to the Cytophaga/Flavobacterium group (CF) [3] was carried out as described in Alfreider et al. [1]. The probes were fluorescently labeled with the indocarbocyanine dye Cy3 (Interactiva, Ulm, Germany). After hybridization, the filter section were stained with $4^{\prime}$,6-diamino-2-phenylindole (DAPI), and the percentage of hybridized bacterial cells enumerated by epifluorescence microscopy. At least 500 DAPI-stained cells per sample were inspected. The mounting medium Citifluor (Citifluor Ldt., Kent UK) was amended with ca. 20\% of VectaShield (Vector Lab., Burlingame, CA, USA). This modification resulted in significantly reduced fading of the probe signal (Pernthaler, pers. comm.), which allowed a more reliable measurement of hybridized cells (see below).

\section{Cell Dimensions of Hybridized Cells}

Cell dimensions of the two most important subgroups affiliated to BETA and CF were inferred from their DAPI-stained images to facilitate comparison with the size structure of the total bacterial community. Pairs of images of the Cy3 and DAPI fluorescence of individual cells in microscopic preparations were captured using the PC-based image analysis system LUCIA G/F 4.0 by means of a digitized monochrome LCD camera DVC 1300 mounted on an Olympus AX 70 PROVIS epifluorescence microscope. Between 400 and 800 hybridized cells were analyzed per sample (corresponding to 6 to 20 image pairs). For details of the procedure used and the statistical evaluation see Pernthaler et al. [25]. To depict longitudinal shifts in biomass size distribution of BETA and CF along the reservoir, we subdivided hybridized cells into five size categories based on cell length as described above for biomass size distribution of total DAPI-stained bacterial cells.

\section{Protozoan Grazing and Abundance}

To measure protozoan grazing upon bacterioplankton, we used fluorescently labeled bacterioplankton (FLB; for more details see Simek et al. [37]). For grazing experiments, 250-500 ml of replicated samples were dispensed into acid soaked and rinsed 1-liter flasks and incubated at in situ temperature. Flagellate and ciliate uptake rates were determined in the same treatment where FLB added constituted $5-18 \%$ of bacterial natural abundances. Thirtymilliliter subsamples for protozoan enumeration and tracer ingestion determinations were taken at $0,5,10,15,20$, and 30 min after tracer addition and fixed by adding $0.5 \%$ of alkaline Lugol's solution, immediately followed by $2 \%$ borate-buffered formaldehyde (final concentration) and several drops of $3 \%$ sodium thiosulfate to clear the Lugol's color [34]. We determined ciliate grazing rates in time series from 5-15 min subsamples and flagellate grazing rates in subsamples from 10-30 min, respectively (for details see Šimek et al. [37] and Comerma et al. [10]). Samples from zero time were also inspected to avoid a potential bias of our data due to attachment of noningested tracers on protozoan surfaces. Five-milliliter (flagellates) or 20-30 $\mathrm{ml}$ (ciliates) subsamples were stained with DAPI, filtered through $1-\mu \mathrm{m}$ black Poretics filters, and inspected via epifluorescence microscopy. Nonpigmented, heterotrophic nanoflagellates (HNF) and plastidic flagellates were always differentiated. At least 50 ciliates and 100 flagellates were inspected for FLB ingestion in each sample. Uptake rates of the tracers were calculated from the changes of average number of tracers per protozoan cell with time using linear regression. To estimate total protozoan grazing, we multiplied average uptake rates of ciliates and flagellates by their in situ abundances.

\section{Results}

Samples were collected at nine sampling points along the longitudinal axis of the Sau Reservoir in April and July 1997, i.e., at different parts of the season and under different temperatures. Nevertheless, a high input of allochtonous organic material, which entered the canyon-shaped reservoir with the organically loaded Ter river [4], induced generally similar longitudinal trends in the selected microbial parameters and bacterial community composition (BCC) (see Figs. 2-6).

Bacterial abundance, biomass, and mean cell volume decreased remarkably and bacterial cell size class distributions significantly shifted, from the organically polluted river (station 9) downstream to the dam area (station 1). For instance, bacterial abundance dropped by a factor of 3.42 and 2.94, bacterial biomass by a factor of 10.3 and 5.57, and bacterial cell volume by a factor of 5.08 and 2.21 in April and July, respectively (Figs. 2 and 3). These changes were also paralleled by a strong shift from the numerical dominance of bacterial cells with length $>1 \mu \mathrm{m}$ (65-70\% of total bacteria) in the river inflow to the dominance of the smaller cell size categories $<1 \mu \mathrm{m}(84-88 \%$ of total bacteria) near the dam (Fig. 4). However, the contributions of the two largest bacterial size categories, i.e., $2-3 \mu \mathrm{m}$ long and $>3 \mu \mathrm{m}$, differed remarkably in April and July as they accounted for 32 and $13 \%$ of total bacterial abundance, but they comprised as much as 73 and $29 \%$ of total bacterial biomass, respectively. Thus, while the general trends in the above bacterial parameters were very similar (Figs. 2-4) in both seasons, their absolute values in the river inflow in April, i.e., $16.1 \times 10^{6}$ bact $\mathrm{ml}^{-1}$, mean cell volume of $0.6 \mu \mathrm{m}^{3}$, bacterial biomass of 

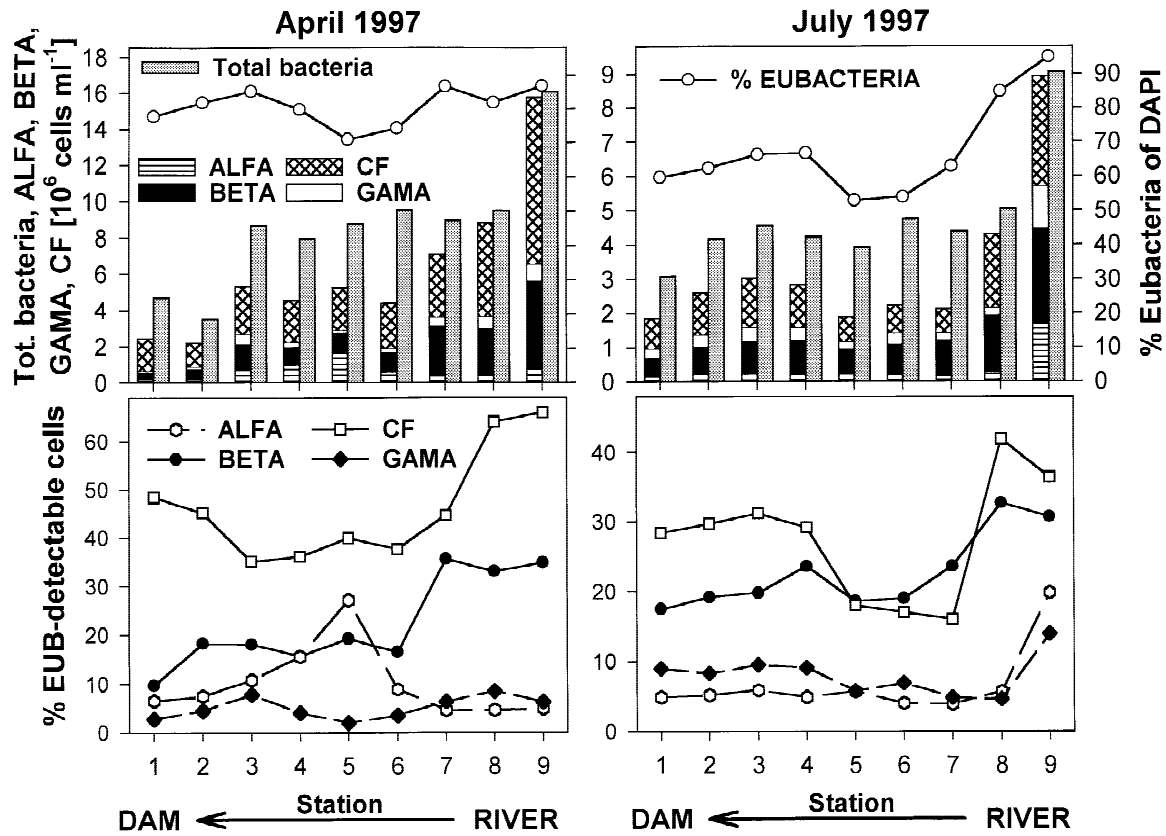

Fig. 2. Longitudinal changes in microbial parameters along the Sau Reservoir in April (left panels) and July 1997 (right panels): Total numbers of DAPI-stained bacteria and of bacteria targeted with the probes for ALFA-, BETA-, GAMA-Proteobacteria, and Cytophaga/Flavobacterium (CF) group, the proportion of Eubacteria (EUB) in total DAPI-stained bacteria, and relative proportions of the groups ALFA, BETA, GAMA, and CF within the cells hybridized with the EUB probe. Note that there are different scales for the data from April and July. All the values represent mean of duplicate treatments.

$1166 \mu \mathrm{g} \mathrm{L}^{-1}$ of organic carbon, and $>20 \%$ of large filamentous bacteria $(>3 \mu \mathrm{m})$, were much higher than in July. Clearly a pronounced input of allochthonous bacterial populations to the upper, riverine part of the reservoir (stations 8 and 9) occurred in April, corresponding also to a higher flow rate of the river inflow.

The most dramatic changes in bacterial parameters occurred between stations 9 to 7 (Figs. 2-5), being spatially associated with the position of the plunge point, i.e., the transient zone between riverine and lacustrine part of the reservoir. Based on water temperature, stratification and other water quality parameters (for details see Armengol et al. [4] and references therein) we determined that the plunge point was just above station 7 in April and slightly upstream, closer to station 8 , in July. In both cases, between these two stations the surface river water flow began to mix with the reservoir water masses.

Fluorecence in situ hybridization with the five oligo-

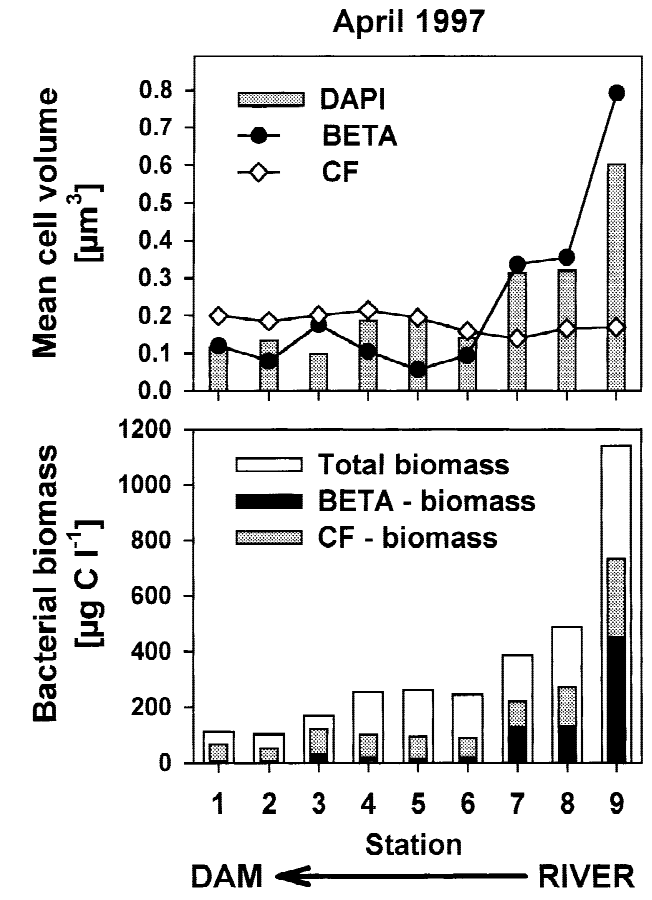

April 1997
Fig. 3. Longitudinal changes in microbial parameters along the Sau Reservoir in April (left panels) and July 1997 (right panels): Bacterial mean cell volume based on all DAPI-stained bacteria and separately on only those cells, which hybridized with the probe for BETA-Proteobacteria (BETA) and Cytophaga/Flavobacterium group (CF); total bacterial biomass and contributions of the BETA and CF biomasses into total bacterial biomass. Note that there are different scales for the data from April and July. All the values represent mean of duplicate treatments. 


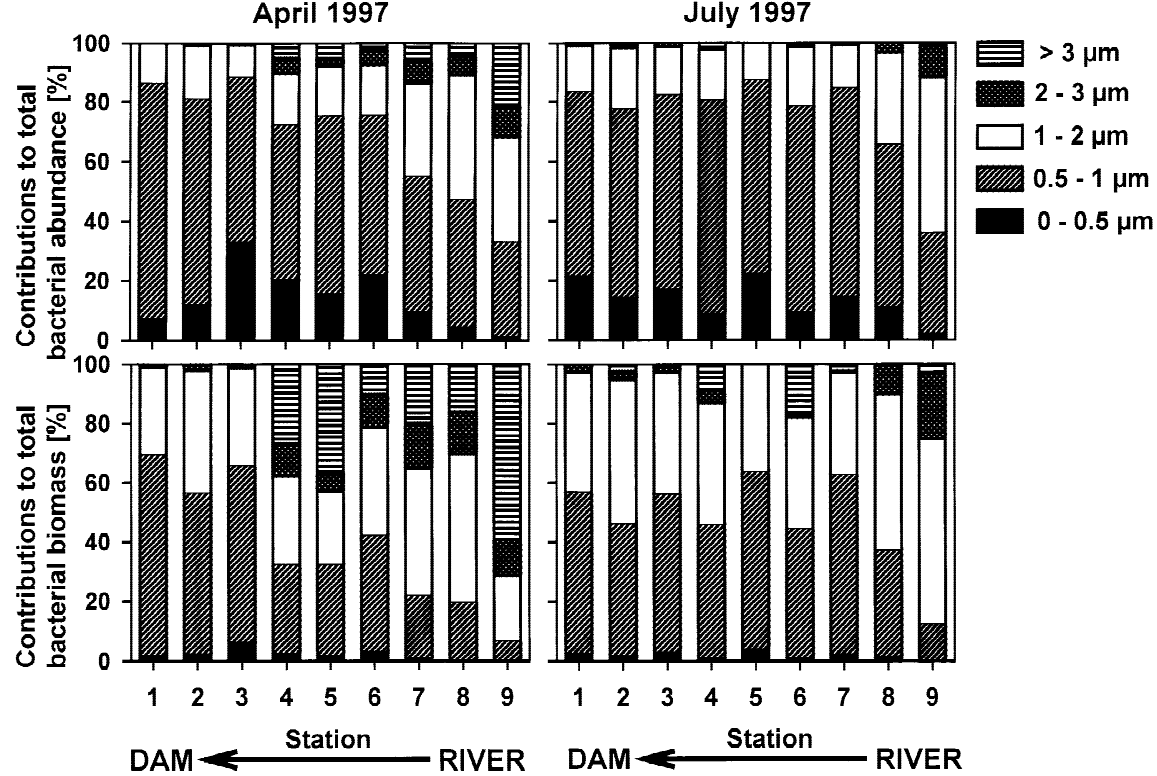

Fig. 4. Longitudinal changes in microbial parameters along the Sau Reservoir in April (left panels) and July 1997 (right panels): Contributions of different size classes of bacteria to total bacterial abundance and biomass. nucleotide probes revealed the conspicuous changes in bacterial community composition between stations 8 and 7, or between stations 7 and 6 (e.g., BETA in April; Fig. 2). These changes were reflected namely by (i) a significant drop (Tukey HSD test, $P<0.05$ ) in absolute numbers as well as in the relative contributions of CF to EUB (i.e., in total bacterial numbers hybridized with the probe for Eubacteria), from $\sim 66$ to $37 \%$ and from 42 to $16 \%$, and (ii) a less marked decrease for total numbers and portions of bacteria affiliated to the BETA lineage, from 35 to $\sim 16 \%$ (significant between stations 6 and 7) and from 32 to 19\%, in April and July, respectively. CF increased to $48 \%$ of EUB-detectable cells at the dam area in April. In July, CF increased between stations 5 and 4 to $\sim 30 \%$ of EUB and then slightly decreased downstream. No marked longitudinal changes occurred in the proportions of BETA in the lacustrine part of the reservoir, i.e., from station 6 downstream (Fig. 2).

The members of the ALFA and GAMA lineages accounted generally for $\sim 3-10 \%$ of EUB and showed little longitudinal variability (Fig. 2). We recorded only two exceptions from this pattern: (i) increased proportions of ALFA were found at stations 4 and 5 (15 and 27\% of EUB, respectively) in the April transect, with a significant increase between stations 6 and 5 (Tukey HSD test, $P<0.05$ ), and (ii)

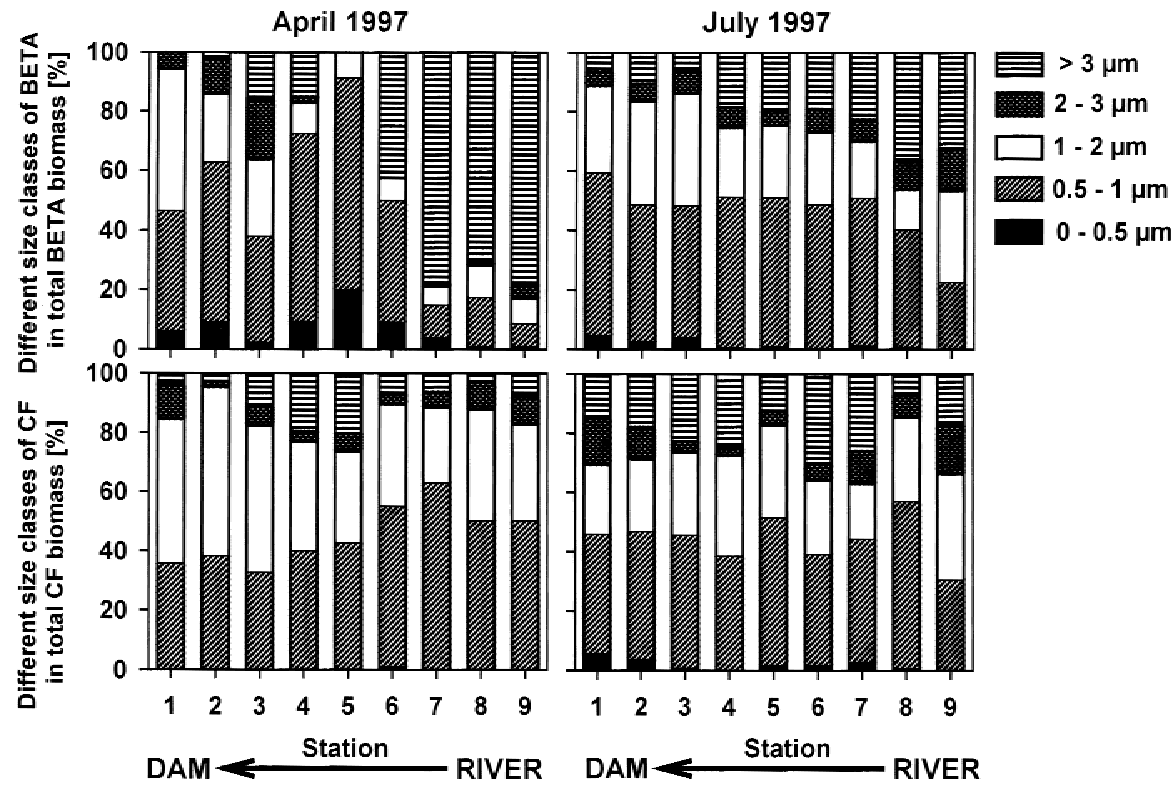

Fig. 5. Longitudinal changes in microbial parameters along the Sau Reservoir in April (left panels) and July 1997 (right panels): Contributions of different size classes of bacteria hybridized with the probes for BETA-Proteobacteria (BETA) and Cytophaga/Flavobacterium (CF) to total biomass of bacteria affiliated to the BETA and CF phylogenetic lineages. 


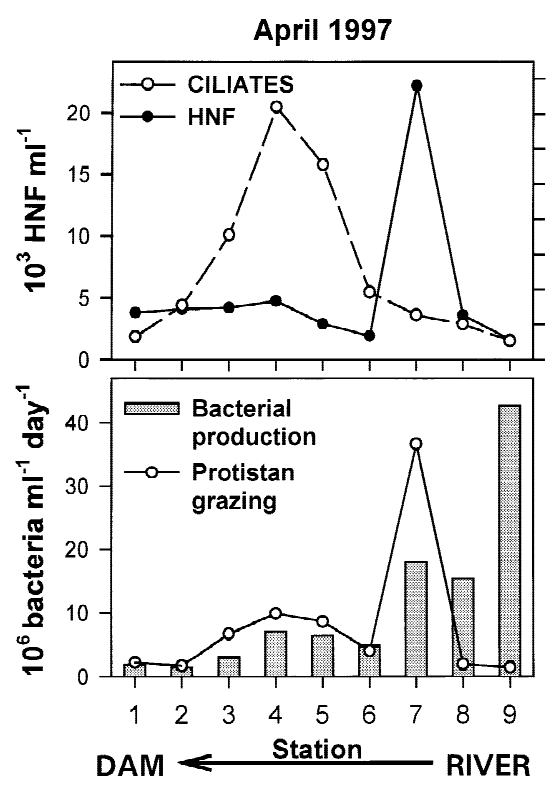

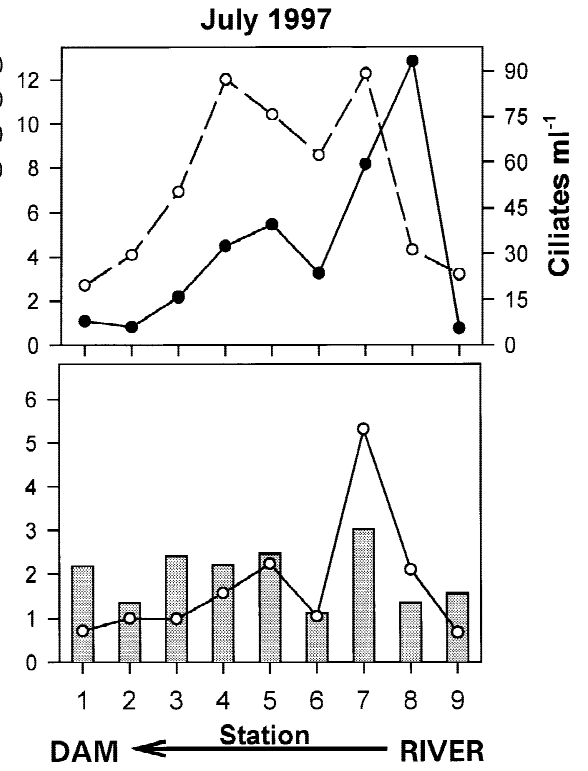

Fig. 6. Longitudinal changes in microbial parameters along the Sau Reservoir in April (left panels) and July 1997 (right panels): Total heterotrophic nanoflagellate (HNF) and ciliate abundance, bacterial production and total protistan bacterivory (the details on cell-specific and community grazing rate and composition of both protistan groups in April and July have been discussed elsewhere $[10,37])$. Note that there are different scales for the data from April and July. All the values represent mean of duplicate treatments. in July, these two groups showed enhanced proportions only in the river inflow in parallel with the highest portion of total DAPI-stained bacteria hybridized with the EUB probe. The sharp drop in the ALFA proportions between stations 9 and 8 was significant (Tukey HSD test, $P<0.05$ ). In April, the percentage of EUB over total bacteria ranged between 70 to $87 \%$ with no marked longitudinal trend, as opposed to the July transect when the proportion of EUB (60-95\%) showed a trend similar to that found for BETA and CF. The decrease in the proportions of EUB between stations 8 and 6 was significant (Tukey HSD test, $P<0.05$ ).

Processing of double images (i.e., of the Cy3 and DAPI fluorescence) of individual cells enabled us (i) to determine longitudinal changes in mean cell volume of the most abundant members of the BETA and CF groups (Fig. 3), (ii) to evaluate the contributions of different size classes within BETA and CF to their respective total biomass (Fig. 5), and (iii) to estimate their contributions to the total bacterial biomass derived from DAPI-stained images (Fig. 3). Cell volume of DAPI-stained bacteria decreased from the river to dam areas, and these changes coincided with the decreasing cell volume of bacteria hybridized with the BETA probe (Fig. $3)$, yielding highly significant correlations $\left(r^{2}=0.909\right.$ and $0.888, n=9, P<0.001)$ in April and July. While cell volume of DAPI-stained bacteria was strongly influenced by the changing cell volume of BETA, no similar correlation was found between the former parameter and the CF size $\left(r^{2}=\right.$ 0.209 and 0.047, $n=9, P=0.216$ and 0.576) in April and July, respectively. Thus, as opposed to BETA, no clear longitudinal patterns in average cell size and the size class dis- tributions of CF (Figs. 3 and 5), with a generally low morphological diversity dominated by short rods, were recorded. Although CF belonged into smallest hybridized cells in the river inflow, their average size was larger than that of all the DAPI-stained bacteria in the lower part of the reservoir. Correspondingly, it resulted in the most marked contribution (30-42\%) of BETA to total bacterial biomass in the upper, inflow part of the reservoir and of the members of CF in the lower part of the reservoir (25-65\%, Fig. 3).

The high input of the allochthonous bacterial biomass into the riverine part of the reservoir obviously induced a marked downstream pattern in the microbial succession, areas dominated by for example, bacteria-heterotrophic nanoflagellates-ciliates (cf. Figs 2 and 6). Only bacterial production data from July slightly deviated from this general downstream pattern, i.e., production was not proportional to the high bacterial biomass in the river inflow. The high bacterial abundance $\left(\sim 16\right.$ and $9 \times 10^{6}$ cells $\left.\mathrm{ml}^{-1}\right)$ and biomass (1166 and $480 \mu \mathrm{g} \mathrm{C} \mathrm{L}^{-1}$ ) in the river inflow (station 9) corresponded to a sharp peak in hetrotrophic nanoflagelate

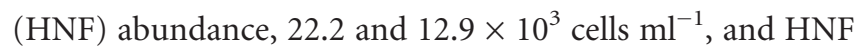
bacterivory, with the latter parameter roughly doubling bacterial production at stations 7 and 8 in April and July, respectively. Spatially, the peaks in protistan bacterivory (Fig. 6) corresponded to the position of the plunge point and to the most remarkable shifts in BCC (cf. Fig. 2). In April, ciliates showed a conspicuous abundance peak at station 4 ( 144 cells $\mathrm{ml}^{-1}$ ), and two peaks in July, at stations 7 and 4 (89 and 87 cells $\mathrm{ml}^{-1}$ ). The above-described succession resulted also in a different longitudinal pattern of protistan bacte- 
rivory: while HNF prevailed mainly at the upstream stations 9 - 7 (data not shown), ciliates largely balanced or exceeded HNF bacterivory at stations 6 - $2[10,37]$.

\section{Discussion}

To our knowledge, this study is likely the first one describing changing phylogenetic bacterial composition in such a longitudinally dynamic system. Though we used only five different probes, the results clearly showed a shift in BCC and bacterial size structure, and morphology from the riverine towards the lacustrine part of the reservoir (Figs. 2-5) likely reflecting the change from the allochthonous, riverborne to the autochthonous reservoir bacteria. The BCC shifts we detected in the proportions of BETA and CF were remarkably strong, considering the rather crude splitting of the community into a few subgroups, each of them consisting of an unknown number of bacterial strains [3]. With the rather limited taxonomic resolution level of the probes we might have missed shifts within, e.g., the BETA group. Fortunately, the group-specific rRNA-targeted oligonucleotide probes have proved to be a sufficient tool for characterizing the shifts in BCC in this organically loaded reservoir. The mean cell volume of the reservoir bacterioplankton (between $\sim 0.1-$ 0.2 and $>0.2 \mu \mathrm{m}^{3}$ in the lacustrine and riverine parts of the reservoir, respectively; Fig. 3) and the values of bacterial production (Fig. 6) indicated a high degree of cell-specific physiological activity, and the EUB probe detected 58-96\% of total DAPI-stained bacterial cells. A similar range of values has been reported from oligo- to eutrophic lakes $[1,11$, $26,38,49]$. Except for a few samples from the middle part of the reservoir in the July transect, the EUB probe always targeted $>65 \%$ of total DAPI-stained bacterial cells (Fig. 2).

Sizing of hybridized cells was based on DAPI-stained cells, a procedure that could underestimate size [42], but that facilitates the direct comparison of, e.g., mean cell volumes of the BETA or CF subpopulations with the cell volume or size distribution of the total assemblage (for details see Pernthaler et al. [25]). The average volume of bacteria in this highly eutrophic reservoir was rather large compared to those reported from the epilimnion of other freshwater systems $[9,15,28,48]$ and the cells stained with the Cy3 fluorochrome produced a bright fluorescent signal.

In general, the large bacterial cells in the river inflow (stations 9 and 8) produced the strongest FISH fluorescent signal out of all samples inspected. This implies a high per cell RNA content of the bacteria [30], which was related to their enhanced growth rate in the substrate rich river water. Typically, the sum of cells hybridized with group-specific probes matched well with the total number of the EUBtargeted bacteria in the upper, organically loaded part of the reservoir (Fig. 2). Thus, almost 100\% of FISH-detectable bacteria in the river inflow could be easily affiliated to one of the phylogenetic lineages targeted with the oligonucleotide probes we used. However, in the April transect this was not the case for the lacustrine part of the reservoir (stations 1-6) where between $\sim 5$ and $25 \%$ of EUB-detectable bacterial cells in the lacustrine part of the reservoir likely belonged to other phylogenetic lineages.

The longitudinal changes in the contribution of BETA and $\mathrm{CF}$ bacteria to total numbers were the main responsible of the detected shifts in BCC at the transient zone between the riverine and lacustrine parts of the reservoir (Fig. 2). Nold and Zwart [23] analyzed the occurrence of microbial phyla in freshwater and marine habitats, and they found the following patterns: Gram positive bacteria, ALFA- and GAMA-Proteobacteria were distributed throughout the range of aquatic habitats with ALFA frequently dominating numerically in coastal waters [13], whereas other phylogenetic groups appeared to be more common in narrowly defined aquatic niches, such as anoxic water or sediments ( $\delta$-Proteobacteria), or floating aggregates (CF; see also Weiss et al. [49]). The BETA lineage has been detected in a broad variety of limnetic systems, but sequences related to BETA were largely absent from clone libraries from open ocean environments. BETA often comprised large proportions or even dominate within freshwater bacterial communities involving bacterioplankton $[1,11,26,38]$, lake snow aggregates [49], and activated sludge [21, 47].

In the major features, our data seem to fit the above suggested phylogenetic distribution patterns with a few exceptions. In the Sau Reservoir, not BETA but CF (except for three data points in the July transect, Fig. 2) numerically dominated the community, which contradicts to the usual pattern of BCC in freshwaters (cf. $[12,23])$. The dominance of the CF group not only held for the riverine, nutrient-, and floc-rich part of the reservoir, but was also typically found in the lacustrine part. Moreover, a sharp decrease was apparent in the proportions of $\mathrm{CF}$ at the river-lake transition zone followed by an increase of CF at stations 1-2 and 1-4 in both transects. Thus, it is conceivable that the different composition of the community at the inflow was largely associated with organic substrates of allochthonous origin, whereas the community in the lacustrine areas was largely associated with autochthonous organic substrates produced in the pro- 
cesses of primary production. This documents a broad range of physiological capabilities and substrate flexibility of the phylotypes affiliated to the CF cluster. From pure culture studies, it has been reported that members of the CF group are able to aerobically degrade large spectrum of substrates ranging from various proteins, carbohydrates, pesticides, and insecticides to complex macromolecules [8].

A recent study comparing the $\mathrm{BCC}$ of lakes and oceans [12] reports that the proportions of $\mathrm{CF}$ in freshwaters range from 2 to $12 \%$, averaging $6 \%$ of total bacterial cell count. However, the later values might be biased by a rather limited number of limnetic study sites, covering only four oligo- to mesotrophic lakes. The proportions of CF in bacterioplankton seem to be much more significant within the range of trophic status from meso- (e.g., [49]) through eu- [38] to hypertrophy (the upper, heavily loaded part of the Sau reservoir; see Fig. 2). Moreover, the CF phylotypes have been reported as numerically dominating in the domain Bacteria found on limnetic aggregates [49]. A possible explanation for the very high proportions of $\mathrm{CF}$ in the reservoir could be a general trend of an increasing proportion of particlebound or floc-forming bacteria toward eu- to hypertrophy. The later hypothesis could be supported by our finding that $30-50 \%$ of bacteria in the river inflow were particle bound or floc-forming (data not shown), and correspondingly $\sim 40$ $60 \%$ of total bacteria from this area hybridized with the CF probe. This is the highest percent contribution of CF to total bacterial community that has ever been reported for natural freshwater systems. However, we cannot conclude that the enhanced proportions of CF in eutrophic freshwaters clearly indicate an allochthonous source of water pollution.

For instance, in our size fractionation treatments of plankton samples exposed in dialysis bags in the mesoeutrophic Rímov Reservoir, we found that when the samples were taken during the clear water phase with a very low proportion of bacterial flocs, intensive protistan grazing induced a BCC shift toward increased proportions of CF and ALFA, along with enhanced proportions of grazing-resistant filament- or floc-forming bacteria [38]. In a similar experimental study (Šimek and Horňák, unpub. data), a strong response of bacterioplankton induced by heavy flagellate grazing in the $5 \mu \mathrm{m}$ treatments was observed; BCC shifted towards the dominance of floc-forming ( $70 \%$ of total bacteria) BETA and CF with a typical floc structure of BETA in the outer and $\mathrm{CF}$ in the inner part of such flocs.

Surprisingly, no marked differences in mean cell volumes of the cells targeted with the CF probe (Fig. 3) were found in both longitudinal transects, though there were large differ- ences between the inflow versus lacustrine part of the reservoir in terms of the amount and nature of available organic substrates and the proportion of floc-forming CF. Compared to the conspicuous trend in the mean cell volume of all DAPI-stained bacteria, the mean cell volume of CF was almost constant, thus placing CF within the smallest bacterial cells in the inflow zone but within the largest ones at the dam area of the reservoir (Fig. 3).

On the other hand, the decrease in the proportions of BETA and their reduced cell volumes and biomass from the river downstream might be related to the disappearence of the allochthonous pollution. In the inflow part, we observed a high morphological diversity of the cells that hybridized with the BETA probe, being mostly dominated by flocforming 1-3 $\mu \mathrm{m}$ long rods, robust 3-4 $\mu \mathrm{m}$ long rod-shaped single cells, or by $5-25 \mu \mathrm{m}$ long filaments. The abundant bacterial flocs and morphology of these predominantly large bacterial cells in the river inflow resembled the bacterial community typical of sewage sludge (cf. microphotographs in Manz et al. [21]). This likely reflects the extreme organic matter load, originating from a large population, intensive use of fertilizers, and extensive pig farming in the watershed of the reservoir (for details see Vidal and Om [46]).

Manz et al. [21] and Snaider et al. [40] reported BETA as the dominant group of bacteria in a municipal treatment plant, while rather small cells, affiliated to the CF cluster, clearly prevailed within bacteria from a dairy wastewater plant [21]. The prevalence of BETA and CF in organically highly loaded waters might be a general phenomenon. In our study, the cell size of BETA significantly influenced bacterial mean cell volume, and resulted in the dominance of BETA in the total bacterial biomass from the river inflow downstream to station 7, whereas members of CF numerically dominated throughout the reservoir (Figs. 2 and 3).

No clear conclusion could be drawn from the longitudinal changes in the proportions of ALFA and GAMA subclasses of the class Proteobacteria. Only in the case of the April transect did the enhanced proportions of ALF in the middle part of the reservoir spatially coincide with increased grazing activity of protists, especially of ciliates (for details see Šimek et al. [37]).

Although we clearly detected significant shifts in the bacterial community composition at the transient zone between the riverine and lacustrine parts of the reservoir (Fig. 2), it is rather difficult to unambiguously explain this finding from our data set. Three major factors apparently operated in parallel: complicated hydrology (related to the river flow rate, water temperature, and chemistry), downstream 
changes in substrate availability (allo- versus autochthonous carbon), and protistan bacterivory. Water stratification and the position of the plunge point were probably the most important parameters in determining the position of the marked changes observed in BCC. At the plunge point, situated between stations 7 and 8 , the countercurrents from the river and the reservoir meet, resulting in a partial mixing of water masses. Using conductivity and chloride concentrations as tracers of different water masses, it is has been estimated by a mass balance model (for details see Armengol at al. [4]) that $72-78 \%$ and $~ 14 \%$ of the river inflow was injected into the reservoir epilimnion in the April and July transects, respectively. The strongest influence of the river water injection into the epilimnetic water masses could be detected at the plunge point or close to it. River flow also contributed to the establishment of the downstream trophic gradient through the reservoir (revealed by chemistry, phyto- and zooplankton, and microbial parameters; [4, 10], and see Figs. 2-6 in this paper).

In both transects, the river water mixed with the reservoir epilimnion induced a succession in the microbial food web structure, i.e. bacteria-HNF-ciliates (cf. Figs. 2 and 6). However, the position of peaks of the respective microbial populations and its amplitude seem to be tightly related to the position of the plunge point and to the amount and organic loading of the river water mixed to the epilimnion. Thus, the influence of allochthonous bacterial production was pronounced in April, whereas in July, the peaks in HNF and ciliates abundance had smaller amplitude and they were shifted upstream, closer to the plunge point. In April, protistan bacterivory at the transient zone (around station 7) was almost entirely due to HNF grazing [37], whereas in July, there was also a significant contribution of ciliate grazing, mainly due to the greater ciliate abundances upstream and dominated by typical picoplankton-feeding halteriids [10]. The location of the ciliate peak in July (at station 7) seemed to be related to the position of the plunge point (close to station 8) and by generally higher summer growth rates of protists allowing them to build up large populations quite close to the river inflow.

Protistan grazing is size selective, usually more intense on larger bacterial cells (e.g., $[14,36])$. However, depending on which are the dominant protistan bacterivores in a given freshwater system, bacteria in a certain size range are thought to be protected against HNF grazing (usually between 3 and $5 \mu \mathrm{m}$ long when small bacterivorous HNF dominate $[16,19])$. Large filaments, other large complex growth forms, bacterial aggregates, and particle-bound bac- teria are thus largely resistant to HNF predation [16]. However, these bacterial forms were not likely resistant to the predation by the dominating groups of ciliates (mainly halteriids and vorticellids) and rotifers (400-600 individuals $\mathrm{L}^{-1}$, bdelloids and Brachionus spp.) observed in the upper part of the reservoir $[10,37]$. They can efficiently consume larger prey sizes and also medium-sized bacterial aggregates or detritus particles $[5,37]$, thus specifically contributing to the predation-induced bacterial mortality. Additionally, when the river water masses reach the lacustrine part and are mixed into the reservoir epilimnion, decreased water turbulence facilitates an increased sedimentation rate of larger bacterial aggregates or particle-bound bacteria. Since a large proportion of bacterial flocs was composed of CF and of large cells affiliated to the BETA lineage, these two processes could also selectively contribute to the observed bacterioplankton community composition shift toward the decreased proportions of $\mathrm{CF}$ and BETA at the transient zone of the reservoir (Fig. 2).

It has been reported from both laboratory [17, 27, 39, 45] and field studies $[20,38]$ that intensive flagellate grazing on bacteria can induce a significant shift in BCC. Generally, we found the lowest protistan numbers and bacterivory rates in the river inflow (Fig. 6). In both April and July the high allochthonous bacterial input to the reservoir epilimnion induced a huge HNF development dominated by large bacterivorous chrysomonads just at the plunge point. Protistan bacterivory roughly doubled the bacterial production, spatially corresponding to the most marked changes in bacterial community composition (cf. Figs. 2 and 6). Though we are aware of possible sources of under- or overestimates of the production and grazing data (for the specific discussion related to the Sau Reservoir see Simek et al. [37]), we suggest that the most important biological factor that could significantly contribute to the BCC shifts was flagellate bacterivory.

Longitudinally changing substrate availability and the nature of substrates could also specifically affect the BCC in the reservoir. The riverborne, large, fast-growing bacteria adapted to high substrate concentrations, when reaching the lacutrine part of the reservoir with less substrate and enhanced grazing pressure [36], became less competitive and suffered increased mortality. In contrast, the lacustrine bacterioplankton, composed of smaller bacterial cells (Figs. 3 and 4), likely experienced lower grazing losses and was better adapted to the largely autochthonously produced substrates originating from primary production.

In summary, we found a conspicuous longitudinal gradient in bacterial cell size and community composition, with 
the CF group numerically dominating and BETA accounting for the largest proportion of bacterial biomass in the inflow part of the reservoir. The majority of the large cells affiliated to the BETA lineage disappeared around the plunge point, which spatially coincided with the highest values of protistan bacterivory. Thus, biological processes, i.e., protistan bacterivory and bacterial growth under changing substrate availability, and interplay of the factors related to water chemistry, stratification processes, and increased sedimentation rate of particles at the transient river-reservoir zone were the major forces longitudinally shaping the epilimnetic bacterial community composition. The decreased oxygen saturation of water masses in the upper part of the reservoir did not allowed the development of large filter-feeding cladocerans $[4,10]$ with the ability to crop a broad spectrum of organisms within microbial food webs, including protists [32]. This specific trophic structure contributed to the development of pronounced, longitudinally distinguishable peaks of flagellates and ciliates.

\section{Acknowledgments}

This study was supported by the GA CR research grants $206 / 99 / 0028$ and 206/98/0727, by a project of the Spanish Inter-ministerial Commission of Science and Technology (CICYT, no. HID99-599-CO2-O1), and by the Aigues TerLlobregat Company. Additional supports were also provided by an instrument grant AS CR "Microanalysis of microbial communities"-program 1036, P 1011802, and by a grant of University of South Bohemia CEZ:J06/98:123100004. We thank Thomas Chrzanowski for the English correction of the manuscript, and Jakob Pernthaler, Martin Hahn, Josep Gasol, and Jaroslav Vrba for the valuable comments on the earlier versions of the manuscript.

\section{References}

1. Alfreider A, Pernthaler J, Amann RI, Sattler B, Glöckner F-O, Ville A, Psenner R (1996) Community analysis of the bacterial assemblages in the winter cover and pelagic layers of a high mountain lake using in situ hybridization. Appl Environ Microbiol 62:2138-2144

2. Amann RI, Krumholz L, Stahl DA (1990) Fluorescentoligonucleotide probing of whole cells for determinative, phylogenetic, and environmental studies in microbiology. J Bacteriol 172:762-770

3. Amman RI, Ludwig W, Schleifer KH (1995) Phylogenetic identification and in situ detection of individual microbial cells without cultivation. Microbiol Rev 59:143-169

4. Armengol J, Garcia J-C, Comerma M, Romero M, Dolz J, Roura M, Han B-P, Vidal A, Simek K (1999) Longitudinal processes in canyon type reservoirs: The case of Sau (N.E. Spain). In: Tundisi JG, Straškraba M (eds) Theoretical Reservoir Ecology and Its Applications. Brazilian Academy of Sciences and Backhuys Publishers, Leiden, pp 313-345

5. Arndt H (1993) Rotifers as predators on components of the microbial food web (bacteria, heterotrophic flagellates, ciliates)—a review. Hydrobiologia 255/256:231-246

6. Bell RT (1993) Estimating production of heterotrophic bacterioplankton via incorporation of tritiated thymidine. In: Kemp PF, Sherr BF, Sherr EB, Cole JJ (eds) Handbook of Methods in Aquatic Microbial Ecology. Lewis Publishers, Boca Raton, FL, pp 495-503

7. Berman T (1990) Microbial food-webs and nutrient cycling in lakes: changing perspectives. In: Tilzer MM, Serruya C C (eds) Large Lakes. Ecological Structure and Function. SpringerVerlag, New York, pp 511-525

8. Bernadet JF, Segers P, Vancanneyt M, Berthe F, Kersters K, Vandamme P (1996) Cutting a gordian knot: emended classification and description of the genus Flavobacterium, emended description of the family Flavobacteriacea, and proposal of Flavobacterium hydatis nom. now (basonym, Cytophaga aquatilis strohl and Tait 1978). Int J Syst Bacteriol 46:128-148

9. Chrzanowski TH, Hubbard JG (1988) Primary and secondary production in a Southwestern reservoir. Appl Environ Microbiol 54:661-669

10. Comerma M, Garcia J-C, Armengol J, Romero M, Šimek K (2001) Planktonic food web structure along the Sau Reservoir (Spain) in summer 1997. Internat Rev Hydrobiol 86:195-209

11. Glöckner F-O, Amann R, Alfreider A, Pernthaler J, Psenner R, Trebesius KH, Schleifer KH (1996) An in situ hybridization protocol for detection and identification of planktonic bacteria. Syst Appl Microbiol 19:403-406

12. Glöckner F-O, Fuchs BM, Amann R (1999) Bacterioplankton compositions of lakes and oceans: a first comparison based on fluorescence in situ hybridization. Appl Environ Microbiol 65:3721-3726

13. González JM, Moran MA (1997) Numerical dominance of a group of marine bacteria in the $\alpha$-subclass of the class Proteobacteria in coastal waters. Appl Environ Microbiol 63:4237-4242

14. González JM, Sherr EB, Sherr BF (1990) Size-selective grazing on bacteria by natural assemblages of estuarine flagellates and ciliates. Appl Environ Microbiol 56:583-589

15. Güde H, Haibel B, Müller H (1985) Development of planktonic bacterial populations in a water column of Lake Constance (Bodensee-Obersee). Arch Hydrobiol 105:59-77

16. Hahn MW, Höfle MG (2001) Grazing of protozoa and its effect on populations of aquatic bacteria. FEMS Microb Ecol 35:113-121 
17. Hahn MW, Höfle MG (1999) Flagellate predation on a bacterial model community: Interplay of size-selective grazing, specific bacterial cell size, and bacterial community composition. Appl Environ Microbiol 65:4863-4872

18. Hejzlar J, Vyhnálek V (1998) Longitudinal heterogeneity of phosphorus and phytoplankton concentrations in deep-valley reservoirs. Int Revue Hydrobiol (Spec Issue) 83:139-146

19. Jürgens K, Güde H (1994) The potential importance of grazing-resistant bacteria in planktonic systems. Mar Ecol Prog Ser 112:169-188

20. Jürgens K, Pernthaler J, Schalla S, Amann R (1999) Morphological and compositional changes in a planktonic bacterial community in response to enhanced protozoan grazing. Appl Environ Microbiol 65:1241-1250

21. Manz W, Wagner M, Amann R, Schleifer K-H (1994) In situ characterization of the microbial consortia active in two wastewater treatment plants. Wat Res 28:1715-1723

22. Methé BA, Hiorns WD, Zehr JP (1998) Contrasts between marine and freshwater bacterial community composition: Analyses of communities in Lake George and six other Adirondack lakes. Limnol Oceanogr 43:368-374

23. Nold SC, Zwart G (1998) Patterns and governing forces in aquatic microbial communities. Aquat Ecol 32:17-35

24. Norland S (1993) The relationship between biomass and volume of bacteria. In: Kemp PF, Sherr BF, Sherr EB, Cole JJ (eds) Handbook of Methods in Aquatic Microbial Ecology. Lewis Publishers, Boca Raton FL, pp 303-308

25. Pernthaler J, Alfreider A, Posch T, Andreatta S, Psenner R (1997) In situ classification and image cytometry of pelagic bacteria from a high mountain lake (Gossenköllesee, Austria). Appl Environ Microbiol 63:4778-4783

26. Pernthaler J, Glöckner F-O, Unterholzner S, Alfreider A, Psenner R, Amann R (1998) Seasonal community and population dynamics of pelagic Bacteria and Archaea in a high mountain lake. Appl Environ Microbiol 64:4299-4306

27. Pernthaler J, Posch T, Šimek K, Vrba J, Amann R, Psenner R (1997) Morphological and genotypic shifts in an experimental bacterial community reflecting different bacterial strategies to coexist with a protistan predator. Appl Environ Microbiol 63:596-601

28. Pernthaler J, Sattler B, Šimek K, Schwarzenbacher A, Psenner R (1996) Top-down effects on the size-biomass distribution of a freshwater bacterioplankton community. Aquat Microb Ecol 10:255-263

29. Posch T, Pernthaler J, Alfreider A, Psenner R (1997) Cellspecific respiratory activity of aquatic bacteria studied with the tetrazolium reduction method, cyto-clear slides, and image analysis. Appl Environ Microbiol 63:867-873

30. Poulsen LK, Ballard G, Stahl DA (1993) Use of rRNA fluorescence in situ hybridization for measuring the activity of single cells in young and established biofilms. Appl Environ Microbiol 59:1354-1360
31. Riemann B, Christoffersen K (1993) Microbial trophodynamics in temperate lakes. Mar Microb Food Webs 7:69-100

32. Sanders RW, Wickham SA (1993) Planktonic protozoa and metazoa: predation, food quality and population control. Mar Microb Food Webs 7:197-223

33. Sed'a J, Macháček J (1998) The effect of flow-through regimes on zooplankton densities a canyon-shape reservoir. Internat Rev Hydrobiol (Spec Issue) 83:477-484

34. Sherr EB, Sherr BF (1993) Protistan grazing rates via uptake of fluorescently labeled prey. In: Kemp PF, Sherr BF, Sherr EB, Cole JJ (eds) Handbook of Methods in Aquatic Microbial Ecology. Lewis Publishers, Boca Raton, FL, pp 695-701

35. Šimek K, Armengol J, Comerma M, Garcia J-C, Chrzanowski TH, Macek M, Nedoma J, Straškrabová V (1998) Characteristics of protistan control of bacterial production in three reservoirs of different trophy. Internat Rev Hydrobiol (Spec Issue) 83:485-494

36. Šimek K, Chrzanowski TH (1992) Direct and indirect evidence of size-selective grazing on pelagic bacteria by freshwater nanoflagellates. Appl Environ Microbiol 58:3715-3720

37. Šimek K, Jürgens K, Nedoma J, Comerma M, Armengol J (2000) Ecological role and bacterial grazing of Halteria spp.: small oligotrichs as dominant pelagic ciliate bacterivores. Aquat Microb Ecol 22:43-56

38. Šimek K, Kojecká P, Nedoma J, Hartman P, Vrba J, Dolan JD (1999) Shifts in bacterial community composition associated with different microzooplankton size fractions in a eutrophic reservoir. Limnol Oceanogr 44:1634-1644

39. Šimek K, Vrba J, Pernthaler J, Posch T, Hartman P, Nedoma J, Psenner R (1997) Morphological and genotypic shifts in an experimental bacterial community influenced by protists of contrasting feeding modes. Appl Environ Microbiol 63:587595

40. Snaider J, Amman R, Huber I, Ludwig W, Schleifer K-H (1997) Phylogenetic analysis and in situ identification of bacteria in activated sludge. Appl Environ Microbiol 63:28842896

41. Straškraba M (1998) Limnological differences between deep valley reservoirs and deep lakes. Int Revue Hydrobiol (Spec Issue) 83:1-12

42. Suzuki MT, Sherr EB, Sherr BF (1993) DAPI direct counting underestimates bacterial abundances and average cell size to AO direct counting. Limnol Oceanogr 38:1566-1570

43. Thornton KW, Kimmel BL, Payne FF (1990) Reservoir Limnology: Ecological Perspectives. Wiley and Sons, New York, pp 246

44. Uhlmann D (1991) Anthropogenic perturbation of ecological systems: a need for transfer from principles to applications. In: Ravera O (ed) Terrestrial and Aquatic Ecosystems: Perturbation and Recovery. Ellis Horwood, Chichester, pp 47-61

45. van Hannen EJ, Veninga M, Bloem J, Gons HJ, Laanbroek HJ (1999) Genetic changes in the bacterial community structure associated with protistan grazers. Arch Hydrobiol 145:25-38 
46. Vidal A, Om J (1993) The eutrophication process in Sau Reservoir (NE Spain): A long term study. Verh Internat verein Limnol 25:1247-1256

47. Wagner M, Amann R, Lemmer H, Schleifer K-H (1993) Probing activated sludge with oligonucleotides specific for Proteobacteria: inadequacy of culture-dependent methods for describing community structure. Appl Environ Microbiol 59:1520-1525
48. Weinbauer M, Höfle MG (1998) Size-specific mortality of lake bacterioplankton by natural virus communities. Aquat Microb Ecol 15:103-113

49. Weiss P, Schweitzer B, Amann R, Simon M (1996) Identification in situ and dynamics of bacteria on limnetic organic aggregates. Appl Environ Microbiol 62:1998-2005

50. Weisse T, Stockner JG (1993) Eutrophication: the role of microbial food webs. Mem Ist Itl Idrobiol 52:133-150 